\title{
Article \\ Being Out of the Loop: Workplace Deviance as a Mediator of the Impact of Impression Management on Workplace Exclusion
}

\author{
Triana Fitriastuti ${ }^{1,2, *,+(\mathbb{D})}$ and Alex Vanderstraeten ${ }^{1}$
}

1 Department of Marketing, Innovation, and Organization, Faculty of Economics and Business Administration, Ghent University, 9000 Gent, Belgium; Alex.Vanderstraeten@Ugent.be

2 Department of Management, Faculty of Economic and Business, Mulawarman University, Samarinda 75123, Indonesia

* Correspondence: Triana.Fitriastuti@Ugent.be

† LPDP Awardee. Gedung Danadyaksa Cikini, Jalan Cikini Raya No. 91A-D, Jakarta 10330, Indonesia.

\section{check for}

updates

Citation: Fitriastuti, T.

Vanderstraeten, A. Being Out of the Loop: Workplace Deviance as a Mediator of the Impact of Impression Management on Workplace Exclusion. Sustainability 2022, 14, 1004. https://doi.org/10.3390/ su14021004

Academic Editors: Lucian-Ionel Cioca, Huseyin Arasli, Trude Furunes and Hasan Evrim Arici

Received: 4 December 2021

Accepted: 15 January 2022

Published: 17 January 2022

Publisher's Note: MDPI stays neutral with regard to jurisdictional claims in published maps and institutional affiliations.

Copyright: (c) 2022 by the authors. Licensee MDPI, Basel, Switzerland. This article is an open access article distributed under the terms and conditions of the Creative Commons Attribution (CC BY) license (https:/ / creativecommons.org/licenses/by/ $4.0 /)$.

\begin{abstract}
This study investigates the extending negative effects of impression management (IM) on organizational outcomes in the nursing context. Specifically, this study aims to understand the impact of IM on workplace exclusion through workplace deviance. The data came from 277 head nurses (nurses in leadership positions) in elderly care homes in Belgium. Structured paper-and-pencil questionnaires were administered on site in the respondents' workplaces. In the findings of the current research, IM is positively related to workplace exclusion and the relationship is mediated by workplace deviance. Although, initially, IM is performed by the actors as a natural behavior to maintain their image, at some point, the actors can become fatigued with maintaining their image. Under ego depletion theory, the exhausted IM actors will be highly experienced in deviance or bad performance. Furthermore, consistent with social information processing theory and a correlation study between employees' poor performance and workplace exclusion, the IM actors who fail to deliver good performance or behavior following their like-based rewards may be subject to social exclusion in their workplace.
\end{abstract}

Keywords: impression management; workplace deviance; workplace exclusion; depletion; ego depletion theory; social information processing theory

\section{Introduction}

Over the last decades, the implications of impression management (IM), defined as behaviors used by organizational actors to shape, create, and maintain how they are seen by others [1], have been broadly investigated. Through various study backgrounds and perspectives, IM has both positive and negative effects. The appropriate use of IM strategies and tactics can positively affect individuals when they are associated with specific desired images [2]. In the organizational setting, IM's primary motive is to develop favorable personal attributes and avoid being seen negatively by targets who control valued outcomes. These targets are identified as leaders, interviewers, coworkers, subordinates, and, sometimes, customers [3]. Once individuals portray a positive image (i.e., competence, dedication, and trustworthiness), they may accomplish their goal to gain some personal benefits [4]. These personal benefits include being hired into an organization [5], positive performance evaluation [6], rewards, promotions, social power, being famous, and having a high reputation $[7,8]$.

On the other hand, there is a question of when IM strategies and tactics are applied without skill, sensitivity, and ethical reasoning [9]. Will they create undesirable outcomes? A distinct possibility can be explained with ego-depletion theory $[10,11]$. Based on this theory, employees who perform high levels of IM tactics, such as ingratiation and selfpromotion, can become depleted, leaving them prone to deviance. When employees are depleted, they are less able to resist the temptation to engage in deviant behavior and more 
likely to engage in negative actions [12], causing harm to the organization, its members, and/or its stakeholders [13]. When the IM actors, who are also deviant players, achieve rewards such as likability-based positive performance evaluation and promotion, but workplace competency and valuable performance do not follow, their coworkers likely interpret them as incompetent and unethical workers [14].

Despite extensive research about IM's detrimental effect in organizational settings [15-19], and theoretical studies exploring possible correlations between IM and workplace exclusion $[17,20,21]$, no existing empirical study can adequately explain this relationship. In other words, there might be a possibility that the relationship between IM and workplace exclusion is not straightforward. Therefore, other issues have been raised, including whether IM has multiple downside effects on employee well-being. Based on prior studies, IM contributes to workplace deviance [18] and counterproductive behavior [19]. Along with other consequences, it fosters particular responses that may result in workplace mistreatment, such as social exclusion. Thus, enhanced by ego-depletion theory, this study highlights the need for empirical evidence for the multiple negative effects of IM in organizational settings.

This study took place in the perceived common largest group of healthcare providers: nurses. Although being constantly rated as one of the most trusted and respected professions [22,23], nursing is also categorized as one of the most stressful professions. While facing constant exposure to emotionally demanding circumstances, nurses are mandated to provide excellent service [24]. Not only are nurses required to control their emotions and alleviate the anxiety of patients and their families/guardians [25], but are also expected to maintain this identity among doctors and coworkers [26]. These job demands, in unpredictable and challenging work environments such as during the COVID-19 pandemic, require sustained physical or mental effort and are associated with certain physiological costs [27]. As a matter of fact, a study found that sleep-deprived nurses were more likely to engage in deviant behavior than rested nurses [28].

Since a strong and resilient nursing workforce is crucial to effective healthcare delivery [29], this study aimed to investigate the extending negative effects of IM on organizational outcomes in the nursing context. Specifically, this study aimed to understand the impact of IM on workplace exclusion through workplace deviance.

By doing so, this study provides three main contributions. First, the extant literature on IM has focused on its dysfunctional implications [1], while mostly examining the unexplored effects of multiple downsides. This research brings to light the potential mechanisms responsible for helping to counter this imbalance. Second, to the best of the author's knowledge, no empirical research exists that examines the relationship between IM and workplace exclusion. Thus, this study adds to the ego-depletion theory and social information processing theory literature by proposing and testing workplace deviance as the link between IM and workplace exclusion. Third, this paper contributes to the broader literature in both IM and workplace exclusion by showing how an individual's IM behavior contributes to the antecedents of workplace exclusion through workplace deviance.

\section{Theoretical Background and Hypothesis Development}

\subsection{Impression Management and Workplace Exclusion}

IM is defined as behaviors used by organizational actors to shape, create, and maintain how they are seen by others [1]. The employees, as organizational actors in the workplace, may deliberately cultivate positive images such as likeability, competence, and neediness [30]. IM is commonly applied during employees' performance appraisal [14,31] to maximize rewards and minimize punishments, as well as in career promotion [32].

To accomplish their desired goals, employees can use a variety of IM tactics, such as ingratiation, self-promotion, self-presentation, humblebragging, and exemplification [1]. Among those tactics, previous reviews of the IM literature [1,33] often focused on the use of self-promotion (job-focused) and ingratiation (supervisor-focused). Self-promotion is a job-focused IM behavior, such as alerting employees' supervisors to their own accomplish- 
ments, that is intended to highlight their job competence and performance [34]. In contrast, ingratiation is a career enhancement behavior, such as doing favors or providing compliments directed toward one's supervisor, that is intended to make employees better liked by their supervisors [34,35]. As a social influence tactic, ingratiation is commonly used by employees who are highly dependent on their supervisors to achieve their personal career goals [33]. This act is motivated by supervisors' status and control over important work resources [36]. Ingratiation is also employed as a coping mechanism and adaptive strategy when workers perceive high degrees of organizational politics [37].

Although IM is well known for impacting employees' positive organizational outcomes [1], it is not a risk-free proposition for them. In some circumstances, engaging in IM will raise a question of whether the coworkers of the IM actors will view it as self-serving behavior and respond negatively. If the answer is yes, IM might also result in negative outcomes such as creating an undesirable image among observers [19], which is perceived as deception [38] and unethical [17]. Moreover, IM may possibly be detrimental to the organization itself [39]. IM leads to counterproductive work behavior [19,40], standard ethical violation [17], and feelings of dislike or resentment toward the IM actors [41]. Consequently, other employees, either individually or as a group, will respond negatively to this IM negative behavior with "silent treatment" towards the IM actors, a response also known as workplace exclusion.

Exclusion or ostracism in the workplace is defined as the exclusion, rejection, or ignoring of an individual (or group) by another individual (or group) that hinders an employee's ability to establish or maintain positive interpersonal relationships, workrelated success, or favorable reputation within their workplace [42]. The IM actors are positioned as victims who perceive ostracism as an individual perceiving that they are ignored or excluded by others [43]. This exclusionary behavior can range from avoiding eye contact, failing to invite to lunch, to leaving when the victim enters the room [44]. All of these behaviors could eventually lead to social death in the workplace $[45,46]$

Workplace exclusion, as a negative IM outcome, can be explained by social information processing theory. This theory was developed to explain behaviors and maladjustment when people are involved and interact in social cognitive processes [47]. Based on a few initial observations, individuals tend to create a generalized perception of another person [48]. This information is then recalled to evaluate and respond to the person based on that perception [48]. In this process, emotions are an integrated part [49] and are thought to influence each step of the social information processing model [50].

When the IM actors achieve rewards such as likability-based positive performance evaluation and promotion, but their workplace competency and valuable performance do not follow, coworkers likely interpret them as incompetent and unethical workers [14]. The coworkers may experience feelings such as being stressed, repulsed, contemptuous, and disgusted [51]. To terminate their negative feelings, the coworkers will exclude the IM actors. As a result, the IM actors are likely to be shunned and kept out of the loop of social interaction in the workplace [52]. Therefore, we argue the following:

\section{Hypothesis 1. Impression management is positively related to workplace exclusion.}

\subsection{Workplace Deviance as a Mediator}

Workplace exclusion or ostracism has been linked to deviant behavioral features [20]. A specific deviant behavior in workplace settings is called workplace deviance, defined as "voluntary behavior that violates significant organizational norms and, in so doing, threatens the well-being of the organization or its members, or both" [53]. For organizations, the harmful effects include lost productivity and monetary expenses [54]. For organization members, workplace deviance can negatively impact individual employees' attitudes, affect, and actions [55], such as leading someone to ostracize others [56]. 
Similar to the negative effects of workplace deviance on individuals, IM can also be viewed as an act of threatening the self-interest of others [14]. IM can violate ethical standards [17], push others to conduct similar IM tactics aggressively [57], and also lead to counterproductive work behavior [19] and workplace deviance [18]. Therefore, in this study, we employ workplace deviance as a mechanism to explain the intervening process between IM and workplace exclusion, specifically on how IM actors will be seen as deviant players.

Workplace deviance as a mediator of the relationship between IM and workplace exclusion can be explained by extending ego depletion theory using social information processing theory. Deceptive IM actions, such as daily use of ingratiation and self-promotion, can become difficult to carry out [18]. The established relationships must be maintained and, therefore, can drain employees' self-control resources [38]. Ego depletion theory suggests that when individuals' self-control resources are depleted, they will be less able to resist temptation [58], and more likely to behave defiantly [59]. These individuals will fall into a state of ego depletion, subsequently resulting in impaired self-control performance in the form of deviance [18].

To examine workplace deviance, ego depletion theory is extended by using social information processing theory $[48,49]$. Social information plays a role in coworkers' perception to IM actors [14]. Individuals will use information gathered from themselves and similar others in order to understand and make judgments about the world [60]. As adaptive organisms, individuals adapt attitudes, behaviors, and beliefs to their social context and to the reality of their own past and present behavior and situation [48]. Based on the social information processing approach, when coworkers recognize that the impression management actors employ deviant behavior, they will gather information and use it for determining interactions with impression management actors. Coworkers may react negatively, indicating disapproval towards the impression management actors who may violate group's norms, disrupt group functioning, and potentially threaten group harmony. As a result, social exclusion in the workplace will be applied to prevent further harm to a group by encouraging social stability [61].

Hypothesis 2. The relationship between impression management and workplace exclusion is mediated by workplace deviance.

\section{Methods}

\subsection{Sample and Procedure}

The data from this study, a part of a larger survey, came from head nurses (nurses in leadership positions) in elderly care homes in Belgium. First, we contacted the supervisors of each organization to inform them about our research objectives. They were then asked to identify head nurses who could participate in our study. The potential respondents were informed that their participation would be voluntary and assured that their survey responses would be strictly confidential.

Second, to ensure data quality and validity, structured paper-and-pencil questionnaires were administered on site in the respondents' workplaces [62]. The average time taken to complete the questionnaire was $15 \mathrm{~min}$. The respondents completed peer reports measuring $\mathrm{IM}$, workplace deviance, and workplace exclusion. In total, 108 elderly homes in Belgium were visited, of which 277 head nurses filled out the questionnaire. Fifty-five head nurses were male (19.9\%) and 217 were female (78.3\%). The average age was 45 years old (SD 9.7), ranging from 22 to 74 years, and the average tenure as a head nurse was 11.3 years (SD 8), ranging from 0 to 35 years. See Table 1 for respondents' demographic information. 
Table 1. Descriptive statistics and correlation of variables.

\begin{tabular}{cccccccccc}
\hline & Mean & SD & $\mathbf{1}$ & $\mathbf{2}$ & $\mathbf{3}$ & $\mathbf{4}$ & $\mathbf{5}$ & $\mathbf{6}$ & $\mathbf{7}$ \\
\hline Age & 45.37 & 9.54 & 1 & & & & & & \\
Education & 5.01 & 0.58 & -0.09 & 1 & & & & & \\
Work Tenure & 17.77 & 8.43 & $0.70 * *$ & -0.06 & 1 & & & \\
Gender & 0.78 & 0.41 & 0.01 & -0.04 & 0.00 & 1 & & \\
Impression Management & 2.86 & 0.95 & $-0.26^{* *}$ & $0.14^{*}$ & $-0.16^{* *}$ & 0.06 & 1 & \\
Workplace Deviance & 1.38 & 0.51 & $-0.12^{*}$ & 0.07 & -0.02 & $-0.19^{* *}$ & $0.22^{* *}$ & 1 \\
Workplace Exclusion & 1.92 & 0.60 & -0.08 & 0.11 & 0.00 & -0.10 & $0.16^{* *}$ & $0.38^{* *}$ & 1 \\
\hline & ${ }^{*} p<0.05, * * * 0.01$ & & & & &
\end{tabular}

\subsection{Measures}

In order to obtain high content validity, all measures were derived from the established literature. All survey items were administered in Dutch and rated on a 7-point scale $(1=\mathrm{I}$ completely disagree to $7=$ I completely agree). Cronbach's alpha was used to determine whether the scales were reliable or not. It is preferable to have scores above 0.80 ; however, $0.60-0.70$ are acceptable. The number indicates a high level of the scales' internal consistency with this specific sample [63]. Nevertheless, values higher than 0.95 can be indicated as redundant.

Impression management was measured using peer reports with 16 items developed by Wayne and Ferris [64]. The items have three different dimensions: supervisor-focused tactics, job-focused tactics, and self-focused tactics. Sample items are "takes an interest in supervisor's personal life" for supervisory-focused IM, "she/he works hard when knowing that the results will be seen by supervisor" for self-focused IM, and "tries to take responsibility for positive events even when she/he is not solely responsible" for job-focused IM. In this study, the Cronbach's alpha for the items was 0.88 .

Workplace deviance was measured with 12 items developed by Bennet and Robinson [65], where the respondents were asked to report whether they saw others' deviant behavior at work with a sample item such as "taken an additional or longer break than is acceptable at your workplace". In this study, the Cronbach's alpha for the items was 0.86 .

Workplace exclusion was measured with the 10-item Workplace Ostracism Scale, which assesses exclusionary behavior, developed by Ferris et al. [44]. A sample item is "I ignored him/her at work". In this study, the Cronbach's alpha for the items was 0.84 .

The Demographic control variables in this study included age, education, work tenure, and gender to consider the potential confounding effects on the dependent variables [66]. The first two variables (age and gender) are both significant predictors of the frequency of using IM $[67,68]$. The IM tactics engaged by employees may change when they are older $[67,69]$. Looking at the gender, women are found to use IM less frequently and aggressively than men $[67,68]$. Women prefer to rely on their extra performance and devotion to networking rather than the ingratiation and self-promotion strategies that are more prevalent among men [67]. We also considered work tenure as a control variable, because once workplace relationships are developed, IM may not be very effective in influencing the outcomes [70].

\section{Result}

\subsection{Validity Test}

We conducted factor analysis in SPSS 26. A principal components analysis with varimax rotation method was performed to ensure all items reflected each of the three concepts: IM, workplace deviance, and workplace exclusion.

The Harman single factor technique was used to check the influence of common method bias, where a single factor is accountable for variance in the data [71]. The results showed that all items from each construct were loaded into one factor. In addition, the total variance extracted by one factor was $24.77 \%$. These results indicated that the data may not suffer from common method bias. 
This study employed the Maximum Likelihood method of extraction. To test the overall significance of all of the correlations within the correlation matrix, we utilized Bartlett's test of sphericity, in which the result was significant $\left(x^{2}(703)=6498.9, p<0.0001\right)$. We also checked the Kaiser-Meyer-Olkin measure of sampling adequacy $(\mathrm{KMO}=0.87)$, which exceeded the recommended value of 0.6 . This result indicated that the strength of the relationship among the variables was high.

A series of factor analyses were applied in this study. The analyses emerged three factors explaining a total of $48.286 \%$ of the variance for the entire set of variables. The first factor is workplace exclusion with a high eigenvalue of 9.41 , explaining $24.778 \%$ of the variance. The eigenvalue for IM was 5.42, accounted for $14.268 \%$ of the variance. The last factor is workplace deviance with eigenvalue 3.51, explaining $9.24 \%$ of the variance.

Items loaded lower than 0.50 on their general factors were omitted from further analysis. This is based on Hair et al.'s [72] statement, emphasizing 0.50 or higher as a rule of thumb for the minimum loading of an item with no cross-loadings. In total, four items were omitted from further analysis (Appendix A): three items in factor one (WEX 11, WEX 12, WEX 13) and one item in factor three (WD 3).

\subsection{Descriptive Statistics}

The descriptive statistics were calculated for all study variables. Table 1 shows the significant correlations between IM, workplace exclusion $(\mathrm{r}=0.16, p<0.01)$, and workplace deviance $(r=0.22, p<0.01)$. Based on the demographic variable correlation (Table 1$)$, we found negative relationships between IM and age $(\mathrm{r}=-0.26, p<0.01)$ as well as with the respondents' work tenure $(\mathrm{r}=-0.16, p<0.01)$, confirming that more experienced employees tend to be less engaged with IM. However, all of the demographic variables are uncorrelated to the study variables. To ensure the accuracy of the findings, we conducted regression analysis to test their direct and indirect relationships.

Regression analysis was utilized to test all analyses. To test the mediating role of workplace deviance, we adopted analytical approaches using the PROCESS macro model 4 [73]. According to $[74,75]$, only significant control variables were included in the further step. Thus, all of the control variables that were uncorrelated and not significant in the regression analyses were excluded from the analysis. Table 2 shows that both the direct and indirect effects of IM on workplace exclusion were significant.

Table 2. Regression analysis for mediation of workplace deviance between impression management and workplace exclusion.

\begin{tabular}{|c|c|c|c|c|}
\hline Variable & $B$ & $S E B$ & $\beta$ & $95 \% \mathrm{CI}$ \\
\hline \multicolumn{5}{|l|}{ Step 1} \\
\hline Constant & $1.63^{* * *}$ & 0.114 & & $(1.406,1.856)$ \\
\hline IM-WEX (patch c) & $0.103^{* *}$ & 0.038 & $0.162 * *$ & $(0.028,0.177)$ \\
\hline \multicolumn{5}{|c|}{$R^{2}=0.026, \mathrm{~F}(1275)=7.38, p=0.007$} \\
\hline \multicolumn{5}{|l|}{ Step 2} \\
\hline Constant & $1.036^{* * *}$ & 0.096 & & $(0.847,1.225)$ \\
\hline IM-WD (path a) & $0.121^{* * *}$ & 0.032 & $0.224^{* * *}$ & $(0.058,0.183)$ \\
\hline \multicolumn{5}{|c|}{$R^{2}=0.050, \mathrm{~F}(1275)=14.48, p=0.000$} \\
\hline \multicolumn{5}{|l|}{ Step 3} \\
\hline Constant & $1.185^{* * *}$ & 0.128 & & $(0.934,1.437)$ \\
\hline IM-WEX (path c') & 0.051 & 0.036 & 0.080 & $(-0.020,0.123)$ \\
\hline IM-WD (path b) & $0.430 * * *$ & 0.067 & $0.365^{* * *}$ & $(0.298,0.563)$ \\
\hline \multirow[t]{2}{*}{ Total $(a) *(b)$} & 0.052 & & & $(0.022,0.089)$ \\
\hline & \multicolumn{4}{|c|}{$R^{2}=0.152, \mathrm{~F}(2274)=24.64, p=0.000$} \\
\hline
\end{tabular}


To test hypothesis 1 , proposing that IM is positively related to workplace exclusion, we conducted regression analysis. The coefficient of path $c$ in step 1 was significant $(B=0.103$, $S E=0.038, \mathrm{t}=2.71, p<0.05)$, showing a direct positive association between IM and workplace deviance. Thus, hypothesis 1 is supported.

To test the mediation effect of workplace deviance on IM to workplace exclusion, 5000 bootstrapping samples with unstandardized indirect effects were performed. The model explained $15 \%$ of the variation in workplace exclusion (which was only $2.6 \%$ in step 1 ) with F-statistics of 24.64 and $p<0.001$. In this mediation step, the result demonstrated a significant total effect $(B=0.103, S E=0.038 ; 95 \% \mathrm{CI}(0.028,0.177))$. The results revealed that IM was significant and positively related to workplace deviance as a mediator variable $(B=0.121, S E=0.032 ; 95 \% C I(0.058,0.183))$, and thus, related to workplace exclusion $(B=0.430, S E=0.067 ; 95 \% C I(0.298,0.563))$. The results are illustrated in Figure 1 , path $a$ and $b$.

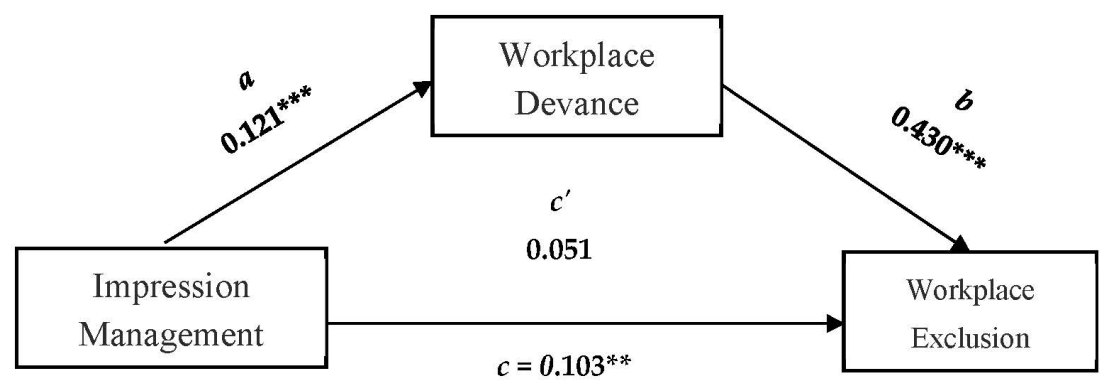

Figure 1. The mediating role of workplace deviance on the relationship between IM and workplace exclusion. Path diagram ${ }^{* *} p<0.01{ }^{* * *} p<0.001$.

The indirect effects were conducted to investigate the role of workplace deviance to explain the mechanism of IM in terms of workplace exclusion. The indirect effects of IM on workplace exclusion through workplace deviance was significant $(B=0.052$, $S E=0.017 ; 95 \%$ CI $(0.022,0.089))$. In this step, the relation of IM and workplace exclusion that was positively significant in step 1, turned out to be insignificant (path $c^{\prime}$ ). These results indicated that workplace deviance fully mediated the relationship between IM and workplace exclusion. In this case, IM no longer affected workplace exclusion after workplace deviance had been controlled [76].

\section{Discussion and Conclusions}

The primary purpose of this study was to examine the impact of IM on workplace exclusion through workplace deviance. Unlike previous research, which mostly focused on the positive outcomes of IM [33,77], our results show that IM also has a negative effect on organizational behavior, such as workplace exclusion. As hypothesized, both concepts are positively related. The significant results confirm that the IM tactics adopted by the actors may backfire [1,17-19]. Although, initially, IM is performed by the actors as a natural behavior to maintain their image, at some point, the actors can become exhausted from maintaining this image. Implementing IM can be time-consuming and involves significant self-control resources [78], requiring considerable effort to eliminate the risk of being suspected to have ulterior motives by the superiors [18,79]. This is difficult to maintain in an ongoing relationship [38]. Moreover, under ego-depletion theory, the exhausted IM actors will be highly experienced in deviance or bad performance.

Consistent with social information processing theory [48] and a correlation study between employees' poor performance and workplace exclusion [21,80], the IM actors who fail deliver good performance or behavior following their like-based rewards may experience social exclusion in the workplace. This finding became one of our concerns. The failure might be caused by the ambiguity of the work environment and inequity in the distribution of rewards. The ambiguity of work situations, associated with ambiguous 
performance standards, make it difficult for employees to know how well they or their coworkers are performing [81]. This may generate job dissatisfaction if the employees perceive that, although ingratiating coworkers have performed at a similar or lower level, they have appeared to be rewarded to a greater degree.

\subsection{Theoretical and Practical Implications}

Theoretically, this study answers one of Bolino's [1] challenges to further explore the implication of IM's varied conceptualizations in organizational contexts. Moreover, this study enriches the IM literature with new knowledge on exploring possible multiple negative effects of IM. While prior studies focused on the effects of IM such as harmful workplace behavior [18,19], this study extends the effects by exploring the phenomenon of workplace exclusion. In addition, this study contributes to the broader literature on IM and workplace exclusion by showing how an individual's IM behavior contributes to the antecedents of workplace exclusion through workplace deviance.

With regard to practical implications, we provide valuable guidance for general management practice. Although leaders may perceive IM as a social lubricant of team functioning [82], they must be alert to the detrimental IM outcomes. This study shows that employees' IM leads to multiple negative effects, such as workplace exclusion and workplace deviance. In this matter, leaders have to be aware of and distinguish between the authentic and deceptive IM practices used by their employees [1,19]. For example, leaders could identify employees' individual competencies that are important to their organization by asking them to take self-assessment measurements. The leaders could then advise and encourage their employees to build their impressions around the highest score competencies as a way to benefit the organization, satisfy individuals' image concerns, and build their personal brand [1].

Another key point to be taken from this study is that, if IM becomes detrimental because it is becoming excessive in the workplace, organizational procedure reformation is suggested. Such implementation in the public sector, including nursing, aims to adopt transparent practices and eliminate favoritism [83]. According to our results, organizations can apply strategic changes; for example, leaders can conduct performance assessments with ratings based on objective outcomes rather than ambiguous performance standards. The best way to assess performance within an organization is through actual performance based on key performance indicators (KPIs). For example, in the nursing sector, the leaders can implement the eight person-centered nursing key performance indicators [84]. Alongside the existing quality indicators, these KPIs will enable nurse leaders to exhibit a high standard of service delivery [85].

In practice, we can infer that when implementing IM, the actors need to be aware that the consistency of delivering good performance and behaviors is also needed. Specifically, peers and human resource practitioners may use this finding as a new indicator or parameter for assessing employees' behavior within a company. A "too good to be true" behavior, such as IM, must be observed by leaders over the long term to check for consistency before making any decisions. Moreover, when the incidence of IM grows, an organization may be able to minimize the number of extrinsic rewards given to employees.

This study also provides implications for nursing management. A European study showed that one out of four Belgian nurses regarded themselves as being burnt out [86]. The demanding work situation and "always on" mentality make nurses experience high emotional exhaustion. Therefore, a covert form of mistreatment from coworkers can aggravate the nurses' mental pressure, resulting in stress. To overcome this problem, nurses can be given a "backstage" space where they can disengage from work and have a chance to be themselves without any concerns of maintaining their image $[87,88]$.

\subsection{Limitations and Directions for Future Research}

We acknowledge a number of limitations of this study. First, our study is crosssectional and includes self-administered data from superiors' perspectives. The causal 
relationship based on this type of protocol must be interpreted carefully. A higher number of respondents and application in different settings and organizations is certainly needed to verify such a causal relationship. As we admit that self-administered data are not free from bias, we performed several remedies to minimize the risk, as suggested by Podsakoff et al. [89].

Second, as our main variables explore negative behaviors within an organization, there is a possibility of biased responses. Although we informed the respondents that their responses would not be published and that their identity would be kept confidential, their true responses might still have been withheld. We suggest that future research applies another method for collecting data that explores a negative outcome. A reflective measurement might be useful.

Third, this study was conducted using a cross-sectional approach, which clearly limits our capacity to discover any potential causal impacts. Future research may choose to use a longitudinal design in order to investigate a process-mediation model and to identify the causal relationships between the variables [90].

Author Contributions: Conceptualization, T.F.; methodology, T.F.; software, T.F.; validation, T.F.; formal analysis, T.F.; investigation, T.F.; resources, T.F.; data curation, T.F.; writing—original draft preparation, T.F.; writing — review and editing, T.F. and A.V.; visualization, T.F.; supervision, A.V.; project administration, T.F.; funding acquisition, T.F. All authors have read and agreed to the published version of the manuscript.

Funding: We gratefully acknowledge financial support from the Indonesia Endowment Fund for Education (LPDP), grant number PRJ-528/LPDP.3/2017.

Institutional Review Board Statement: Our study was conducted in accordance with the ethical code of our university (University of Ghent). We obtained agreement from the directors of the elderly care homes prior to the data collection.

Informed Consent Statement: Informed consent was obtained from all subjects involved in the study.

Acknowledgments: The authors thank Pipiet Larasatie, Radityo Putro Handrito, and Shao Ying. The critiques, comments, and encouragement of the early version of the manuscript were invaluable.

Conflicts of Interest: The authors declare no conflict of interest. The funders had no role in the design of the study; in the collection, analyses, or interpretation of data; in the writing of the manuscript, or in the decision to publish the results.

\section{Appendix A}

Table A1. Factor loadings, communalities based on a principal components analysis with varimax rotation for impression management, workplace exclusion and workplace deviance.

\begin{tabular}{|c|c|c|c|c|c|}
\hline Items & IM & WEX & WD & Communality & Cronbach Alpha \\
\hline IM1 & 0.593 & & & 0.426 & \multirow{14}{*}{0.88} \\
\hline IM2 & 0.581 & & & 0.441 & \\
\hline IM3 & 0.545 & & & 0.400 & \\
\hline IM4 & 0.572 & & & 0.480 & \\
\hline IM5 & 0.510 & & & 0.333 & \\
\hline IM6 & 0.607 & & & 0.378 & \\
\hline IM7 & 0.705 & & & 0.499 & \\
\hline IM8 & 0.733 & & & 0.543 & \\
\hline IM9 & 0.603 & & & 0.373 & \\
\hline IM10 & 0.590 & & & 0.394 & \\
\hline IM11 & 0.696 & & & 0.494 & \\
\hline IM12 & 0.698 & & & 0.514 & \\
\hline IM13 & 0.699 & & & 0.513 & \\
\hline IM14 & 0.694 & & & 0.483 & \\
\hline
\end{tabular}


Table A1. Cont.

\begin{tabular}{|c|c|c|c|c|c|}
\hline Items & IM & WEX & WD & Communality & Cronbach Alpha \\
\hline WEX1 & & 0.758 & & 0.603 & \\
\hline WEX2 & & 0.840 & & 0.738 & \\
\hline WEX3 & & 0.805 & & 0.680 & \\
\hline WEX4 & & 0.670 & & 0.489 & \\
\hline WEX5 & & 0.866 & & 0.800 & \\
\hline WEX6 & & 0.928 & & 0.874 & 0.84 \\
\hline WEX7 & & 0.839 & & 0.722 & \\
\hline WEX8 & & 0.865 & & 0.784 & \\
\hline WEX9 & & 0.881 & & 0.795 & \\
\hline WEX10 & & 0.741 & & 0.559 & \\
\hline WD1 & & & 0.636 & 0.439 & \\
\hline WD2 & & & 0.632 & 0.455 & \\
\hline WD3 & & & 0.474 & 0.245 & \\
\hline WD4 & & & 0.602 & 0.363 & \\
\hline WD5 & & & 0.525 & 0.295 & \\
\hline WD6 & & & 0.516 & 0.283 & 0.86 \\
\hline WD7 & & & 0.713 & 0.524 & \\
\hline WD8 & & & 0.636 & 0.507 & \\
\hline WD9 & & & 0.662 & 0.460 & \\
\hline WD10 & & & 0.726 & 0.550 & \\
\hline WD11 & & & 0.750 & 0.609 & \\
\hline Eigenvalues & 9.41 & 5.42 & 3.51 & & \\
\hline Percentage of variance & 24.778 & 14.268 & 9.240 & & \\
\hline $\begin{array}{c}\text { Kaiser-Meyer-Olkin } \\
\text { measure }\end{array}$ & \multicolumn{5}{|c|}{0.87} \\
\hline $\begin{array}{l}\text { Bartlett's test of } \\
\text { sphericity }\end{array}$ & \multicolumn{5}{|c|}{$x^{2}(703)=6498.9, p<0.0001$} \\
\hline
\end{tabular}

\section{References}

1. Bolino, M.; Long, D.; Turnley, W. Impression Management in Organizations: Critical Questions, Answers, and Areas for Future Research. Annu. Rev. Organ. Psychol. Organ. Behav. 2016, 3, 377-406. [CrossRef]

2. Bolino, M.C.; Klotz, A.; Daniels, D. The impact of impression management over time. J. Manag. Psychol. 2014, 29, 266-284. [CrossRef]

3. Rosenfeld, P.; Giacalone, R.A.; Riordan, C.A. Impression Management in Organizations: Theory, Measurement, Practice; Routledge: London, UK; New York, NY, USA, 1995.

4. Bolino, M.C.; Klotz, A.C. The paradox of the unethical organizational citizen: The link between organizational citizenship behavior and unethical behavior at work. Curr. Opin. Psychol. 2015, 6, 45-49. [CrossRef]

5. Zhao, H.; Liden, R.C. Internship: A recruitment and selection perspective. J. Appl. Psychol. 2011, 96, 221-229. [CrossRef]

6. Hartog, D.N.D.; De Hoogh, A.H.B.; Belschak, F.D. Toot Your Own Horn? Leader Narcissism and the Effectiveness of Employee Self-Promotion. J. Manag. 2018, 46, 261-286. [CrossRef]

7. Diekmann, C.; Blickle, G.; Hafner, K.; Peters, L. Trick or trait? The combined effects of employee impression management modesty and trait modesty on supervisor evaluations. J. Vocat. Behav. 2015, 89, 120-129. [CrossRef]

8. Highhouse, S.; Brooks, M.E.; Wang, Y. Status Seeking and Manipulative Self-presentation. Int. J. Sel. Assess. 2016, $24,352-361$. [CrossRef]

9. Dubrin, A.J. Impression Management in the Workplace: Research, Theory, and Practice; Routledge: New York, NY, USA, 2010.

10. Baumeister, R.F.; Bratslavsky, E.; Muraven, M.; Tice, D.M. Ego depletion: Is the active self a limited resource? J. Pers. Soc. Psychol. 1998, 74, 1252-1265. [CrossRef]

11. Schmeichel, B.J.; Vohs, K.D.; Baumeister, R.F. Intellectual performance and ego depletion: Role of the self in logical reasoning and other information processing. J. Pers. Soc. Psychol. 2003, 85, 33-46. [CrossRef]

12. Lian, H.; Yam, K.C.; Ferris, D.L.; Brown, D. Self-Control at Work. Acad. Manag. Ann. 2017, 11, 703-732. [CrossRef]

13. Spector, P.E.; Fox, S. The Stressor-Emotion Model of Counterproductive Work Behavior. In Counterproductive Work Behavior: Investigations of Actors and Targets; American Psychological Association: Washington, DC, USA, 2005; pp. 151-174.

14. Wayne, S.J.; Kacmar, M.; Ferris, G.R. Coworker Responses to Others' Ingratiation Attempts. J. Manag. Issues 1995, 7, $277-289$.

15. Crant, J.M. Doing More Harm Than Good: When Is Impression Management Likely to Evoke a Negative Response? J. Appl. Soc. Psychol. 1996, 26, 1454-1471. [CrossRef] 
16. Turnley, W.H.; Bolino, M.C. Achieving desired images while avoiding undesired images: Exploring the role of self-monitoring in impression management. J. Appl. Psychol. 2001, 86, 351-360. [CrossRef]

17. Turnley, W.H.; Klotz, A.; Bolino, M.C. Crafting an image at another's expense: Understanding unethical impression management in organizations. In Handbook of Unethical Work Behavior: Implications for Well-Being; Giacalone, R.A., Promislo, M.D., Eds.; M.E. Sharpe: Armonk, NY, USA, 2013; pp. 123-139.

18. Klotz, A.C.; He, W.; Yam, K.C.; Bolino, M.C.; Wei, W.; Houston, L. Good actors but bad apples: Deviant consequences of daily impression management at work. J. Appl. Psychol. 2018, 103, 1145-1154. [CrossRef]

19. Yan, M.; Xie, Y.-P.; Zhao, J.; Zhang, Y.-J.; Bashir, M.; Liu, Y. How Ingratiation Links to Counterproductive Work Behaviors: The Roles of Emotional Exhaustion and Power Distance Orientation. Front. Psychol. 2020, 11, 2238. [CrossRef] [PubMed]

20. Mao, Y.; Liu, Y.; Jiang, C.; Zhang, I.D. Why am I ostracized and how would I react?-A review of workplace ostracism research. Asia Pac. J. Manag. 2018, 35, 745-767. [CrossRef]

21. O'Reilly, J.; Banki, S. Research in Work and Organizational Psychology: Social Exclusion in the Workplace. In Social Exclusion; Riva, P., Eck, J., Eds.; Springer: Cham, Switzerland, 2016; pp. 133-155. [CrossRef]

22. Morgan, D.G.; Kosteniuk, J.G.; Bello-Haas, V.D.; Stewart, N.J.; Karunanayake, C.; O'Connell, M.E. Dementia-related work activities of home care nurses and aides: Frequency, perceived competence, and continuing education priorities. Educ. Gerontol. 2015, 42, 120-135. [CrossRef]

23. Olshansky, E. Nursing as the Most Trusted Profession: Why This Is Important. J. Prof. Nurs. 2011, 27, 193-194. [CrossRef]

24. Hyde, P.; Harris, C.; Boaden, R. Pro-social organisational behaviour of health care workers. Int. J. Hum. Resour. Manag. 2013, 24, 3115-3130. [CrossRef]

25. Diefendorff, J.M.; Erickson, R.J.; Grandey, A.A.; Dahling, J.J. Emotional display rules as work unit norms: A multilevel analysis of emotional labor among nurses. J. Occup. Health Psychol. 2011, 16, 170-186. [CrossRef]

26. Vandenbroeck, S.; Van Gerven, E.; De Witte, H.; Vanhaecht, K.; Godderis, L. Burnout in Belgian physicians and nurses. Occup. Med. 2017, 67, 546-554. [CrossRef]

27. Ward, L. Mental health nursing and stress: Maintaining balance. Int. J. Ment. Health Nurs. 2011, 20, 77-85. [CrossRef] [PubMed]

28. Christian, M.; Ellis, A.P.J. Examining the Effects of Sleep Deprivation on Workplace Deviance: A Self-Regulatory Perspective. Acad. Manag. J. 2011, 54, 913-934. [CrossRef]

29. Price, S.L.; Hall, L.M.; Angus, J.E.; Peter, E. Choosing nursing as a career: A narrative analysis of millennial nurses' career choice of virtue. Nurs. Inq. 2013, 20, 305-316. [CrossRef]

30. Jones, E.E.; Pittman, T.S. Toward a general theory of strategic self-presentation. In Psychological Perspective on the Self; Suls, J., Ed.; Lawrence Erlbaum: Hillsdale, NJ, USA, 1982; pp. 231-261.

31. Harris, K.J.; Kacmar, K.M.; Zivnuska, S.; Shaw, J.D. The impact of political skill on impression management effectiveness. J. Appl. Psychol. 2007, 92, 278-285. [CrossRef]

32. Bolino, M.C.; Kacmar, K.M.; Turnley, W.H.; Gilstrap, J.B. A Multi-Level Review of Impression Management Motives and Behaviors. J. Manag. 2008, 34, 1080-1109. [CrossRef]

33. Higgins, C.A.; Judge, T.A.; Ferris, G.R. Influence tactics and work outcomes: A meta-analysis. J. Organ. Behav. 2002, 24, 89-106. [CrossRef]

34. Ferris, G.R.; Judge, T.A.; Rowland, K.M.; Fitzgibbons, D.E. Subordinate Influence and the Performance Evaluation Process: Test of a Model. Organ. Behav. Hum. Decis. Process. 1994, 58, 101-135. [CrossRef]

35. Foulk, T.A.; Long, D.M. Impressed by impression management: Newcomer reactions to ingratiated supervisors. J. Appl. Psychol. 2016, 101, 1487-1497. [CrossRef]

36. Baer, M.D.; Dhensa-Kahlon, R.K.; Colquitt, J.A.; Rodell, J.B.; Outlaw, R.; Long, D.M. Uneasy Lies the Head that Bears the Trust: The Effects of Feeling Trusted on Emotional Exhaustion. Acad. Manag. J. 2015, 58, 1637-1657. [CrossRef]

37. Fitriastuti, T.; Larasatie, P.; Vanderstraeten, A. Please Like Me: Ingratiation as a Moderator of the Impact of the Perception of Organizational Politics on Job Satisfaction. Int. J. Environ. Res. Public Heal. 2021, 18, 7455. [CrossRef]

38. Carlson, J.R.; Carlson, D.S.; Ferguson, M. Deceptive Impression Management: Does Deception Pay in Established Workplace Relationships? J. Bus. Ethic 2010, 100, 497-514. [CrossRef]

39. Appelbaum, S.H.; Hughes, B. Ingratiation as a political tactic: Effects within the organization. Manag. Decis. 1998, 36, 85-95. [CrossRef]

40. Yam, K.C.; Klotz, A.; He, W.; Reynolds, S.J. From Good Soldiers to Psychologically Entitled: Examining When and Why Citizenship Behavior Leads to Deviance. Acad. Manag. J. 2017, 60, 373-396. [CrossRef]

41. Keeves, G.D.; Westphal, J.D.; McDonald, M.L. Those Closest Wield the Sharpest Knife: How Ingratiation Leads to Resentment and Social Undermining of the CEO. Adm. Sci. Q. 2017, 62, 484-523. [CrossRef]

42. Hitlan, R.T.; Clifton, R.J.; DeSoto, M.C. Perceived exclusion in the workplace: The moderating effects of gender on work-related attitudes and physical health. N. Am. J. Psychol. 2006, 8, 217-235.

43. Williams, K.D.; Orgas, J.P.; Von Hippel, W.E. The Social Outcast: Ostracism, Social Exclusion, Rejection, and Bullyings; Psychology Press: New York, NY, USA, 2005.

44. Ferris, D.L.; Brown, D.J.; Berry, J.W.; Lian, H. The development and validation of the Workplace Ostracism Scale. J. Appl. Psychol. 2008, 93, 1348-1366. [CrossRef] [PubMed] 
45. Macdonald, G.; Leary, M.R. Why Does Social Exclusion Hurt? The Relationship between Social and Physical Pain. Psychol. Bull. 2005, 131, 202-223. [CrossRef] [PubMed]

46. Baumeister, R.F.; DeWall, C.N.; Mead, N.L.; Vohs, K.D. Social Rejection Can Reduce Pain and Increase Spending: Further Evidence That Money, Pain, and Belongingness Are Interrelated. Psychol. Inq. 2008, 19, 145-147. [CrossRef]

47. Van Reemst, L.; Fischer, T.F.C.; Zwirs, B.W.C. Social Information Processing Mechanisms and Victimization: A Literature Review. Trauma Violence Abus. 2014, 17, 3-25. [CrossRef]

48. Salancik, G.R.; Pfeffer, J. A Social Information Processing Approach to Job Attitudes and Task Design. Adm. Sci. Q. 1978, 23, 224. [CrossRef]

49. Crick, N.R.; Dodge, K.A. A review and reformulation of social information-processing mechanisms in children's social adjustment. Psychol. Bull. 1994, 115, 74-101. [CrossRef]

50. Harper, B.D.; Lemerise, E.A.; Caverly, S.L. The Effect of Induced Mood on Children's Social Information Processing: Goal Clarification and Response Decision. J. Abnorm. Child Psychol. 2009, 38, 575-586. [CrossRef] [PubMed]

51. Dunn, J.; Ruedy, N.E.; Schweitzer, M.E. It hurts both ways: How social comparisons harm affective and cognitive trust. Organ. Behav. Hum. Decis. Process. 2011, 117, 2-14. [CrossRef]

52. Haidt, J. The New Synthesis in Moral Psychology. Science 2007, 316, 998-1002. [CrossRef]

53. Robinson, S.L.; Bennett, R.J. A Typology of Deviant Workplace Behaviors: A Multidimensional Scaling Study. Acad. Manag. J. 1995, 38, 555-572. [CrossRef]

54. Bennett, R.J.; Marasi, S.; Locklear, L. Workplace Deviance; Oxford University Press: New York, NY, USA, 2019.

55. Robinson, S.L.; Wang, W.; Kiewitz, C. Coworkers Behaving Badly: The Impact of Coworker Deviant Behavior upon Individual Employees. Annu. Rev. Organ. Psychol. Organ. Behav. 2014, 1, 123-143. [CrossRef]

56. Hales, A.H.; Wesselmann, E.D.; Williams, K.D. Prayer, self-affirmation, and distraction improve recovery from short-term ostracism. J. Exp. Soc. Psychol. 2016, 64, 8-20. [CrossRef]

57. Frink, D.D.; Ferris, G.R. Accountability, impression management, and goal setting in the performance evaluation process. Hum. Relat. 1998, 51, 1259-1283. [CrossRef]

58. Tangney, J.P.; Baumeister, R.; Boone, A.L. High Self-Control Predicts Good Adjustment, Less Pathology, Better Grades, and Interpersonal Success. J. Pers. 2004, 72, 271-324. [CrossRef]

59. Gino, F.; Schweitzer, M.E.; Mead, N.; Ariely, D. Unable to resist temptation: How self-control depletion promotes unethical behavior. Organ. Behav. Hum. Decis. Process. 2011, 115, 191-203. [CrossRef]

60. Festinger, L. A Theory of Social Comparison Processes. Hum. Relat. 1954, 7, 117-140. [CrossRef]

61. Williams, K.D.; Sommer, K.L. Social Ostracism by Coworkers: Does Rejection Lead to Loafing or Compensation? Pers. Soc. Psychol. Bull. 1997, 23, 693-706. [CrossRef]

62. Richman, W.L.; Kiesler, S.; Weisband, S.; Drasgow, F. A meta-analytic study of social desirability distortion in computeradministered questionnaires, traditional questionnaires, and interviews. J. Appl. Psychol. 1999, 84, 754-775. [CrossRef]

63. Cortina, J.M. What is coefficient alpha? An examination of theory and applications. J. Appl. Psychol. 1993, 78, 98-104. [CrossRef]

64. Wayne, S.J.; Ferris, G.R. Influence tactics, affect, and exchange quality in supervisor-subordinate interactions: A laboratory experiment and field study. J. Appl. Psychol. 1990, 75, 487-499. [CrossRef]

65. Bennet, R.J.; Robinson, S.L. Development of a measure of workplace deviance. J. Appl. Psychol. 2000, 85, 349-360. [CrossRef]

66. Kamdar, D.; Van Dyne, L. The joint effects of personality and workplace social exchange relationships in predicting task performance and citizenship performance. J. Appl. Psychol. 2007, 92, 1286-1298. [CrossRef]

67. Singh, V.; Kumra, S.; Vinnicombe, S. Gender and Impression Management: Playing the Promotion Game. J. Bus. Ethic 2002, 37 , 77-89. [CrossRef]

68. Bolino, M.C.; Turnley, W.H. More Than One Way to Make an Impression: Exploring Profiles of Impression Management. J. Manag. 2003, 29, 141-160. [CrossRef]

69. Bourdage, J.S.; Roulin, N.; Tarraf, R. "I (might be) just that good": Honest and deceptive impression management in employment interviews. Pers. Psychol. 2018, 71, 597-632. [CrossRef]

70. Crawford, W.S.; Kacmar, K.M.; Harris, K.J. Do You See Me as I See Me? The Effects of Impression Management Incongruence of Actors and Audiences. J. Bus. Psychol. 2018, 34, 453-469. [CrossRef]

71. Chang, S.-J.; Van Witteloostuijn, A.; Eden, L. From the Editors: Common method variance in international business research. J. Int. Bus. Stud. 2010, 41, 178-184. [CrossRef]

72. Hair, J.F.; Black, W.C.; Babin, B.J.; Anderson, R.E. Multivariate Data Analysis; Prentice Hall: Upper Saddle River, NJ, USA, 2010.

73. Hayes, A.F. Introduction to Mediation, Moderation, and Conditional Process Analysis: A Regression-Based Approach; The Guilford Press: New York, NY, USA, 2013.

74. Becker, T. Potential Problems in the Statistical Control of Variables in Organizational Research: A Qualitative Analysis with Recommendations. Organ. Res. Methods 2005, 8, 274-289. [CrossRef]

75. Bernerth, J.B.; Aguinis, H. A Critical Review and Best-Practice Recommendations for Control Variable Usage. Pers. Psychol. 2015, 69, 229-283. [CrossRef]

76. Baron, R.M.; Kenny, D.A. The moderator-mediator variable distinction in social psychological research: Conceptual, strategic, and statistical considerations. J. Pers. Soc. Psychol. 1986, 51, 1173-1182. [CrossRef] 
77. Westphal, J.D.; Stern, I. The Other Pathway to the Boardroom: Interpersonal Influence Behavior as a Substitute for Elite Credentials and Majority Status in Obtaining Board Appointments. Adm. Sci. Q. 2006, 51, 169-204. [CrossRef]

78. Vohs, K.D.; Baumeister, R.F.; Ciarocco, N.J. Self-Regulation and Self-Presentation: Regulatory Resource Depletion Impairs Impression Management and Effortful Self-Presentation Depletes Regulatory Resources. J. Pers. Soc. Psychol. $2005,88,632-657$. [CrossRef]

79. Leary, M.R.; Kowalski, R.M. Impression management: A literature review and two-component model. Psychol. Bull. 1990, 107, 34-47. [CrossRef]

80. Quade, M.J.; Greenbaum, R.L.; Mawritz, M.B. "If Only My Coworker Was More Ethical": When Ethical and Performance Comparisons Lead to Negative Emotions, Social Undermining, and Ostracism. J. Bus. Ethics 2018, 159, 567-586. [CrossRef]

81. Gabriel, A.S.; Koopman, J.; Rosen, C.C.; Johnson, R.E. Helping others or helping oneself? An episodic examination of the behavioral consequences of helping at work. Pers. Psychol. 2017, 71, 85-107. [CrossRef]

82. Nguyen, N.T.; Seer, A.; Hartman, N.S. Putting a Good Face on Impression Management: Team Citizenship and Team Satisfaction. J. Behav. Appl. Manag. 2008, 9, 148-168. [CrossRef]

83. Borges, R.; Quintas, C.A. Understanding the individual's reactions to the organizational change: A multidimensional approach. J. Organ. Chang. Manag. 2020, 33, 667-681. [CrossRef]

84. McCance, T.; Telford, L.; Wilson, J.; MacLeod, O.; Dowd, A. Identifying key performance indicators for nursing and midwifery care using a consensus approach. J. Clin. Nurs. 2011, 21, 1145-1154. [CrossRef]

85. McCance, T.; Dickson, C.A.W.; Daly, L.; Boomer, C.A.; Brown, D.; Lynch, B.; MacArthur, J.; Mountain, K.; McCormack, B. Implementing person-centred key performance indicators to strengthen leadership in community nursing: A feasibility study. $J$. Nurs. Manag. 2020, 28, 1443-1452. [CrossRef]

86. Aiken, L.H.; Sermeus, W.; Smith, H.L.; Kutney-Lee, A.; van den Heede, K.; Sloane, D.M.; Busse, R.; McKee, M.; Bruyneel, L.; Rafferty, A.M.; et al. Patient safety, satisfaction, and quality of hospital care: Cross sectional surveys of nurses and patients in 12 countries in Europe and the United States. BMJ 2012, 344, e1717. [CrossRef] [PubMed]

87. Harrison, M.A.; Smith, W.R.; Greenwell, M.R.; Stephens, K.K. Frontline employees in the health clinic: Impression management multiplexing when performing in-the-round. Commun. Monogr. 2018, 85, 309-330. [CrossRef]

88. Lewin, S.; Reeves, S. Enacting 'team' and 'teamwork': Using Goffman's theory of impression management to illuminate interprofessional practice on hospital wards. Soc. Sci. Med. 2011, 72, 1595-1602. [CrossRef]

89. Podsakoff, P.M.; MacKenzie, S.B.; Lee, J.Y.; Podsakoff, N.P. Common method biases in behavioral research: A critical review of the literature and recommended remedies. J. Appl. Psychol. 2003, 88, 879-903. [CrossRef]

90. Maxwell, S.E.; Cole, D.A. Bias in cross-sectional analyses of longitudinal mediation. Psychol. Methods 2007, 12, 23-44. [CrossRef] 